https://doi.org/10.52449/1857-4114.2021.37-1.09

CZU: 796.015.3: 796.422.14

\title{
BUILDING OF STRENGTH TRAINING FOR MIDDLE DISTANCE RUNNERS AGED 13- 14 YEARS-OLD IN AUTUMN - WINTER MACROCYCLE
}

\author{
Svecla Svetlana ${ }^{1}$, ORCID: 0000-0003-4773-8275 \\ Gorascenco Alexandr' ${ }^{2}$, ORCID: 0000-0002-8269-7862 \\ ${ }^{1,2}$ State University of Physical Education and Sport, Chisinau, Republic of Moldova
}

\begin{abstract}
The article presents data on the effective building of strength training for middle distance runners in the autumn - winter macrocycle. It was revealed that the conjugated-sequential form of organizing loads of various predominant directions provides for a strict procedure for introducing loads into the process of training athletes with a gradually increasing degree of specificity and strength of the training influence. It was determined that in the six-month training cycle for middle-distance runners aged 13-14 years-old, the conjugated-sequential form of organizing loads with the element of concentration of strength loads has a more beneficial effect on the dynamics of the level of motor training than the complex-parallel one.
\end{abstract}

Keywords: strength training, autumn-winter macrocycle, middle distance running, stage of initial sports specialization, concentration of loads.

Introduction. At present, there is no doubt that the rationality of the system of strength training (ST) contributes to an increase in the efficiency of training middle-distance runners in general. At the same time, the effectiveness of the ST itself largely depends on such factors as: the algorithm and the duration of the accentuated use of strength loads in training cycles of various duration; a combination of loads in the means of running training (RT) and strength training (ST) of various predominant orientation; the value of "concentration" of loads aimed at the development of strength abilities, their dynamics in the annual cycle [1, 2, 4, 8, etc.].

Usually, the accentuated use of training loads in the means of the ST was planned at the end of the preparatory periods. Somewhat later, it was shifted to its middle. However, in both cases, it was envisaged to reduce their volume by the beginning of the competition periods. Despite the fact that in competitive periods the loads in the means of SP, albeit in a minimal volume, are still used, and the decline in their stiffness is compensated for by the influence of a group of means of RP of high intensity, the level of special working capacity of middle-distance runners, and at the same time, and their athletic performance has degraded. Due to the fact that the dynamics of the level of development of motor abilities during this period is proportional to the changes in the indicators of the power potential of runners, experts see this as a cause-and-effect relationship $[2,3,4,5,8$, etc.].

Research methodology and organization. In order to determine the most effective building of strength training in the annual cycle of training middle-distance runners, a six-month pedagogical experiment was carried out in the research. It was attended by 13-14 year-old runners, specializing in middle distance running (SISS - Stage of Initial Sports 
Specialization, qualification 1 junior category), $(n=21)$. The experiment was carried out in the period from 1.09.2011 to 1.03.2012 on the basis of the Specialized Sports School of Athletics of the Ministry of Education, Culture and Research, Chisinau $(n=6)$ and Balti $(n=$ 3), as well as SSCYOR (Specialized School for Children and Youth of the Olympic Reserve) no 2, Tiraspol $(\mathrm{n}=12)$.

As an experimental factor in the study, the organization of the ST of middle-distance runners on SISS was taken.

The experiment covered the autumn winter macrocycle. It had a duration of 26 weeks, 8 of which were allocated for the competition period (January - February). Among the main starts of the season are the competitions planned for 19-28.02.2012 (Championship and Championship of the Republic of Moldova).

The traditional variant of ST construction (complex - parallel organization, uniform distribution) were tested by the runners of the experimental group "A" $(n=12)$. In the preparation of the runners of the group "B", a modified version of the building of the ST was used.
Results and their discussion. Two options for organizing a ST were subject to comparison. Variants of the were compared within the framework of conjugate - sequential and complex - parallel forms of organizing impacts of various predominant directions. Distribution of impacts in running training equipment (RT) in the compared variants had the same character. Schematic diagrams of constructing impacts of various predominant directions in macrocycles are presented below (Figures 1 - 3).

As a result of a relatively even distribution of loads, sooner or later, the athlete's body adapts to these influences, and, accordingly, the degree of their "stressfulness" decreases. As a result, the response of the organism to the mastered influences becomes less pronounced and therefore the "force" of the effect on the stimulus vanishes over time. This stimulates the desire to increase the total volume of the load, which often became an end in itself. Excessive enthusiasm for volumetric loads, unjustifiably early intensification and specialization of training of young athletes, and in fact, its forcing, leads to a breakdown in adaptation, violation of the laws of the formation of their sportsmanship.

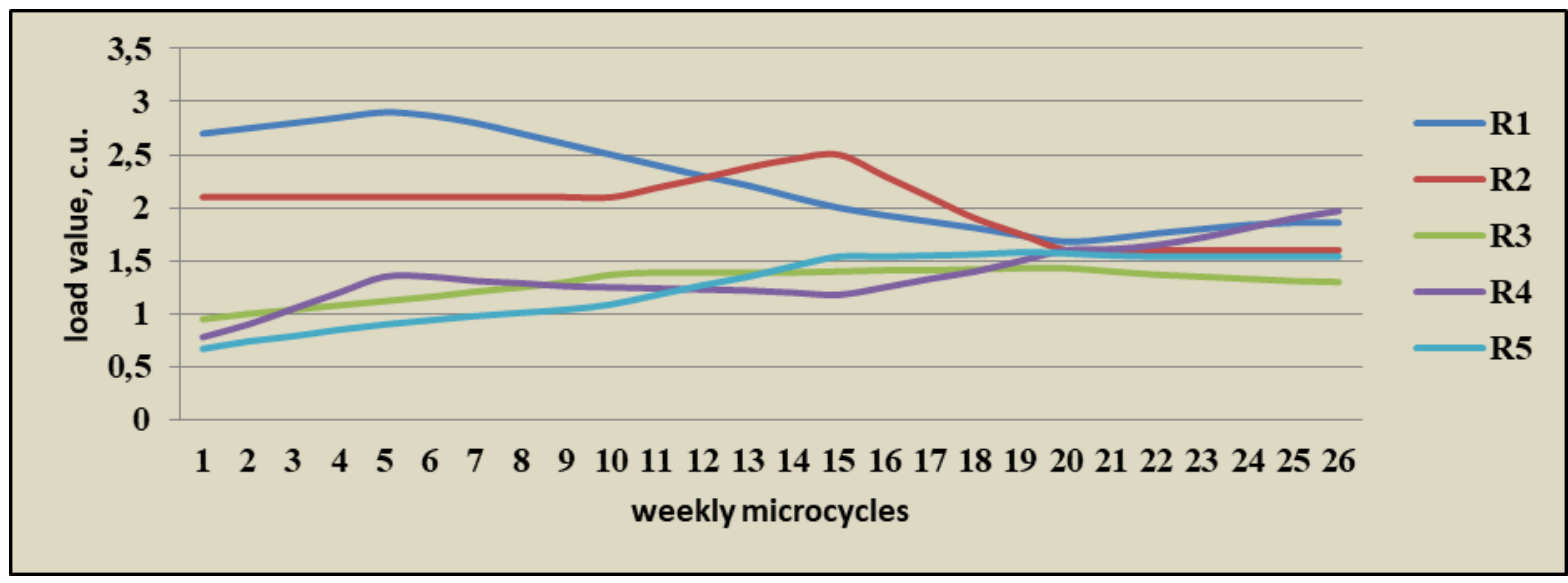

Fig. 1. Scheme of a complex - parallel organization of running loads in the autumn - winter macrocycle of training middle distance 13-14 year-old runners

Designation: R1 - aerobic loads (maintenance mode); R2 - loads of an aerobic nature (developmental regimen); R3 - loads of aerobic-anaerobic nature; R4 - loads of alactic nature; R5 lactate loads 
Among the disadvantages of this organization of loads include the unsystematic use of funds from the arsenal of the ST, used mainly for the development of strength and as an "addition" to the solution of the main tasks of training [2, $3,4,6$, etc.].

In connection with the above, the young group of runners (A), who tested this approach in the experiment, should be considered a control one.

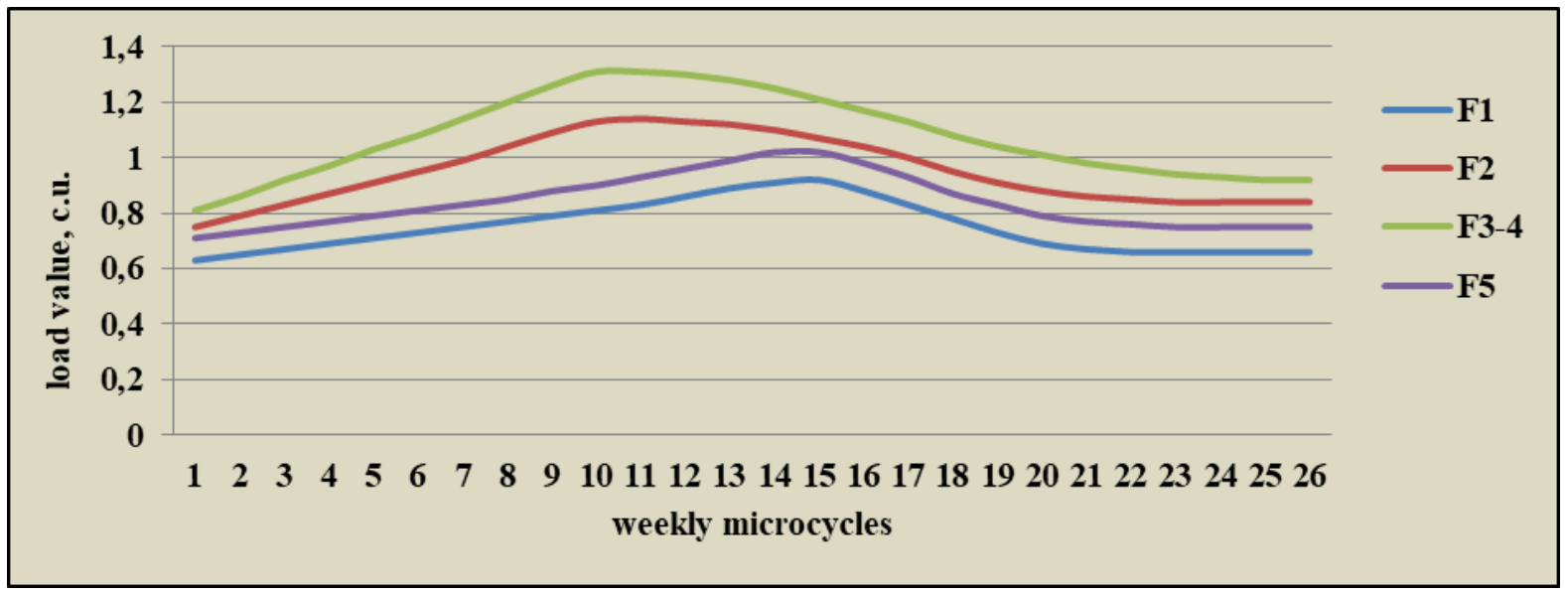

Fig. 2. Scheme of a complex-parallel organization of strength loads in the autumn - winter macrocycle of training middle distance 13-14 year-old runners

Designation: F1 - load the self-power orientation; F2 - loads aimed at the development of LM and strength endurance; F3-4 - loads aimed at the development of explosive and speed strength; F5 loads aimed at the development of speed-strength endurance

The program of runners of group "B", which was based on the form of conjugated sequential organization of loads of various predominant directions, provides for a strict procedure for introducing loads into the process of training athletes with a gradually increasing degree of specificity and strength of the training influence, as well as expedient succession in the order of their use. It assumes such a sequence of their distribution, when some impacts purposefully create a favorable background for the subsequent development of loads of a different predominant orientation.

A peculiarity of this form of organizing loads is also the concentration of training influences of a homogeneous nature, i.e. their concentration, within the boundaries of certain structural components of the annual cycle and "dilution in time" of loads of different predominant directions. Their concentration is able to ensure the "massiveness" of a specific effect on the athlete's body, and their "dilution in time" will contribute to the achievement of a sustainable adaptive effect from the use of each of them. Moreover, it is associated - the sequential organization of loads of various predominant directions with elements of concentration of unidirectional influences within the boundaries of individual microcycles should cover the entire macrocycle [2, 3, 6, 7, 9]. 


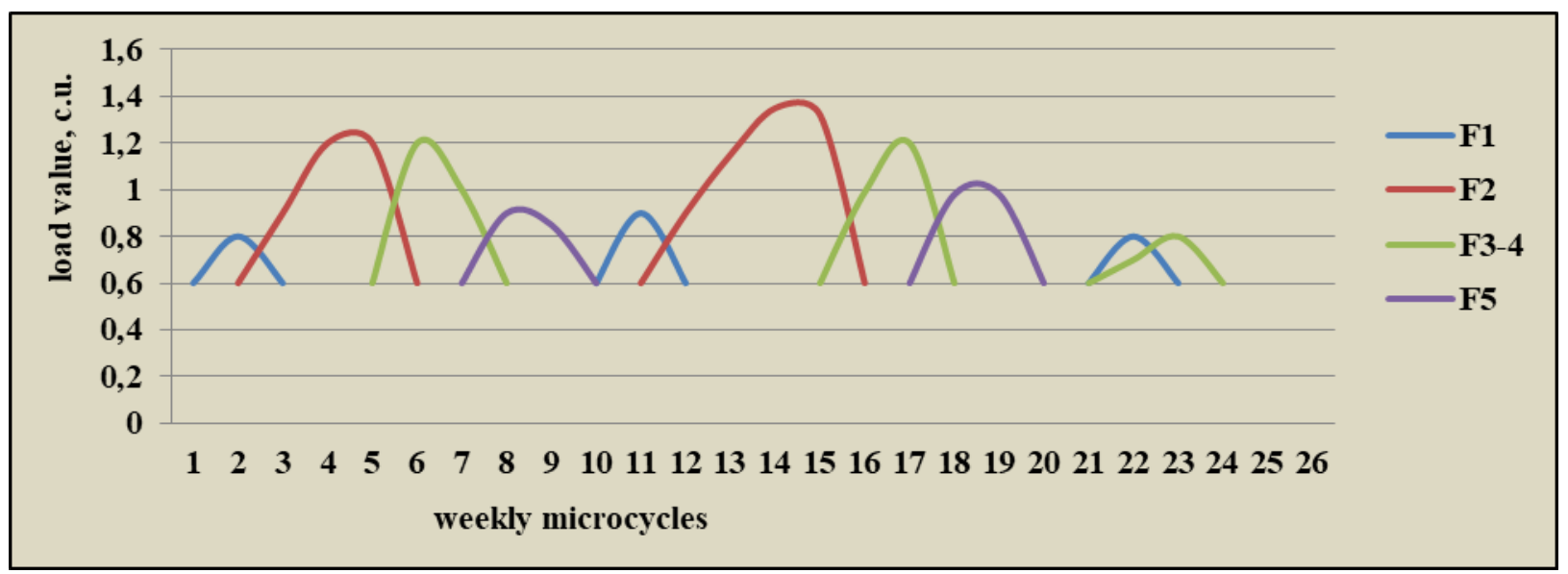

Fig 3. Scheme of the conjugate-sequential organization of strength loads in the autumn - winter macrocycle of training middle distance 13-14 year-old runners

Designation: F1 - load the self-power orientation; F2 - loads aimed at the development of LM and strength endurance; F3-4 - loads aimed at the development of explosive and speed strength; F5 loads aimed at the development of speed-strength endurance

The foregoing formed the basis of the conjugate variant - the consistent organization of strength training, which was designed within the framework of the concept of $\mathrm{Yu}$. Verkhoshanskiy [2,3].

The content of the ST was grouped taking into account their direction in five blocks (F1 F5). The duration of their primary use is $1-5$ weeks, and the period of their accentuated use is no more than two weeks. Variation of loads in the means of ST $0.7-1.3 \mathrm{c} . \mathrm{u}$. The sequence of introducing ST blocks into the training process is as follows: block of self-strength orientation (F1); block LMV and strength endurance (F2); explosive and high-speed power unit (F3-4); block of speed-strength endurance (F5). Such a sequence of including blocks in the training process is considered scientifically grounded, and therefore logically justified. The age, as well as the level of the runners' motor training, determined the time parameters of the described cycle application. Experts consider its two-fold application lasting 12 weeks to be expedient and quite feasible. During the period of performance in the main starts of the season, the use of means of the ST arsenal is not provided [2, 3, 5, 9, $10]$.

The element of relative concentration is observed exclusively in loads F2 and F3-4. This is due to the fact that the level of development of LMW and power endurance, on the one hand, and speed-power abilities, on the other, determines the state of the specific working capacity of middle-distance runners. This means that their development predetermines a high degree of probability of increasing the effectiveness of competitive activity (CA).

An equally important condition for ST at this age is its predominant antiglycolytic orientation. Naturally, it is practically impossible to avoid the use of loads performed in the lactate zone of energy supply, due to the specifics of the sport chosen for specialization. Systematic and long-term use of loads of the glycolytic zone leads to uncompensated fatigue, accompanied by a significant decline in working capacity and, as a result, to the inability of athletes to master training loads of the required value. At the same time, one should take into account the fact that a characteristic feature of the MD of this type of 
athletics is its implementation, mainly in this mode. In this connection, it is necessary to provide for the gradualness of their adaptation to the very requirements that MD runners place on the body - relatively long-term reproduction of rather powerful motor acts against the background of gradually developing fatigue $[2,3,7,8]$.

It should be noted that the SP was carried out within the framework of three forms of its implementation: in the form of a separate training; in the form of implemented blocks of this direction; in the form of ST means based on the "principle of conjugate impact".

Conclusions. It has been experimentally confirmed that the "conjugated-sequential" form of organization of loads of a non-uniform orientation in a six-month training cycle for middle-distance 13-14 year-old runners with an element of concentration of strength-related loads has a more beneficial effect on the dynamics of the level of motor training than the "complex-parallel" one. The program approved by gr. B made it possible not only to reach the level of fulfillment of the proper standards of preparedness and target tasks in a competitive exercise in $77.7 \%$ of cases, while in gr. A these indicators are equal to $64.9 \%$ and $54.1 \%$, respectively. The variant used by gr. B also ensured the timeliness of reaching the level of maximum values throughout the test block - $77.7 \%$. In gr. A this figure is $59.5 \%$, while the norm for this criterion is $75.0 \%$.

\section{References:}

1. Бондарчук А. (2005). Периодизация спортивной тренировки. Киев: Олимпийская литература. 303 с.

2. Верхошанский Ю. (1988). Основы специиальной силовой подготовки спортсменов. Москва: Физкультура и спорт. 331 с.

3. Верхошанский Ю. (1985). Программирование и организация тренировочного проиесса. Москва: Физкультура и спорт. 176 с.

4. Гетманец В., Травин Ю. (1987). Построение силовой тренировки в годичном циикле. В: Легкая атлетика. 1987, №11, с. 4-5

5. Горащенко А., Свекла С., Ларионов В. (2019). Метамарфозы взглядов на силовую подготовку юных бегунов на выносливость. În: Aктуальные научные исследования в современном мире, № 2 (46), Ч- 4, с. 35-46.

6. Козловский Ю. (1980). Скоростно-силовая подготовка бегунов на средние дистанщии. Киев: Здоров'я. 132 с.

7. Набатникова М. (1983). О критериях оптимальности в подготовке юных спортсменов. В: Особенности построения тренировки юных спортсменов. Москва: ВНИИФК, с. 17-27.

8. Сиренко В., Жданович Л. (1983). Распределение объемов средств силовой направленности в круглогодичной тренировке и его значение для развития силовых способностей бегунов на средние дистанции. В: Объективизация методики управления основными параметрами тренировочных нагрузок. Киев: КГИФК, с. 43-52.

9. Свекла С. (2018). Формы организации нагрузок в годичном цикле подготовки юных бегунов на средние дистанции. În: Актуальные научные исследования в современном мире, 1 , Ч- 3, c. $154-161$.

10. Povestca L. (2012). Pregztirea de forюz - vitezz a semifondistului rapid $(800 \mathrm{~m})$ : Monografie. Chiєinru: Primex - Com SRL. 143 p. 